\title{
Studies on Genetic Variability in Chilli (Capsicum annuum L.) in the Sundarban Region of West Bengal
}

\author{
Chandan Kumar Mondal ${ }^{1 *}$, Pinaki Acharyya ${ }^{2}$ and Pranab Hazra ${ }^{3}$ \\ ${ }^{1}$ Ramkrishna Ashram KVK, Nimpith, South 24 Parganas, West Bengal, India \\ ${ }^{2}$ Department of Horticulture, Institute of Agricultural Science, University of Calcutta \\ ${ }^{3}$ Department of Vegetable Science, Faculty of Horticulture, Bidhan Chandra Krishi \\ Viswavidyalaya, Mohanpur, Nadia, West Bengal, India \\ *Corresponding author
}

\section{A B S T R A C T}

\begin{tabular}{|l|}
\hline Ke y w or d s \\
Chilli, Genetic \\
Variability, \\
Sundarban \\
\hline Article Info \\
\hline $\begin{array}{l}\text { Accepted: } \\
\text { 14 November } 2020 \\
\text { Available Online: } \\
\text { 10 December } 2020\end{array}$ \\
\hline \hline
\end{tabular}

Chilli is one of the important vegetable as well as spice crop of India. India ranks first in dry chilli production worldwide. Chilli is used throughout the world as a spice and also in the making of beverages and medicines. Since time immemorial chilli is an indispensible part of Indian diet. There are more than 400 cultivars of chilli grown all over the world. Few of them are praised for their red colour because of the pigment 'capsanthin,' while others are known for 'hotness' due to presence of alkaloid 'capsaicin.' It is reported that chilli helps in boosting immune system and lowering of cholesterol. India is rich source of genetic variability of chilli with different quality factors. Limited efforts have been made to release location specific suitable varieties. There is an urgent need and vast scope of evaluating and developing location specific varieties having higher yield potential. In the present investigation thirty seven diverse chilli genotypes were assembled from different parts of India to study their performance in the Sundarban region of West Bengal. The genetic information gathered on yield and yield attributing traits would be of utility in formulation of an efficient breeding programme for the improvement of chilli crop as well as to develop promising genotypes/ hybrids.

\section{Introduction}

Chilli (Capsicum annum L.) is one of the most important vegetable as well as spice crop, indispensable in every Indian diet due to its pungency, spicy taste and appealing colour and flavour. It has a predominant position among the spices grown all over India. The production share of chillies among the major spices in India is 25-26 percent (Nandeshwar and Bharad, 2019). Chilli is praised for it's two important qualities, the pungency due to a crystalline acrid volatile alkaloid called Capsaicin and captivating red colour due to the pigment Capsanthin. In India, major chilli producing states are Andhra Pradesh, Orissa, Maharashtra, West Bengal, Karnataka, Rajasthan, Uttar Pradesh and Tamil Nadu (Rajamanickam, 2020). It is reported that majority of the chilli are grown through open 
pollinated varieties which have been in cultivation for a long period of time thus leading to low average productivity.

India is an important chilli producing nation in the world sharing $43.4 \%$ of global dry chilli production (Anon., 2018a). However, productivity of green chilli is only $11.6 \mathrm{t} / \mathrm{ha}$ (produces 35.92 lakh tonnes green chilli from an area of 3.09 lakh hectare land) (Anon., $2018 \mathrm{~b}$ ), which is very low compared to world productivity (14.90 t/ha) (Apeda, 2007). To improve productivity, development of highyielding varieties is of urgent need. Evaluating and developing location specific varieties having higher yield potential are also important. Limited efforts have been made so far, to release location specific suitable varieties. Selection from the existing variations is the most effective breeding procedure. There are more than 400 cultivars of chilli grown all over the world. India is also a rich source of genetic variability of chilli with different quality factors (Nandi, 1992). To improve yield and other characters, information on genetic variability is of great importance and is a prerequisite for the effective screening of superior accessions (Burton, 1952).

The critical assessment of nature and magnitude of variability in the germplasm stock is the important pre-requisite for formulating effective breeding methods as the genetic improvement of any crop depends on magnitude of genetic variability and the extent of heritability of economically important characters (Jogi et al., 2017). Cramer (2006) suggested that selection based upon multiple characters at the same time may reduce the effectiveness of making improvements in a single trait. It is essential to partition the overall variability into its heritable and non-heritable components with the help of genetic parameters like genotypic co-efficient of variation, heritability and genetic advance over mean (Vidyashree et al., 2018). Hence the present study was undertaken to determine the extent of genetic variability for important growth and yield characters, interrelationship among the characters and their direct and indirect effects on yield of chilli.

\section{Materials and Methods}

Experimental location: The field experiment was conducted at the Instructional Farm of Ramkrishna Ashram Krishi Vigyan Kendra, Nimpith, South 24 Parganas, West Bengal consecutively for three years, i.e. during the rabi season of 2008-09, 2009-10 and 2010-11. The Instructional Farm is situated at $88^{0} 28^{\prime}$ East longitude, $22^{0} 22^{\prime}$ 'North latitude, in the coastal saline zone of West Bengal within the Sundarban ecosystem with an altitude of $3.75 \mathrm{~m}$ above mean sea level.

Experimental material: The experimental material comprised of 37 chilli genotypes assembled from different parts of India (Assam, Nagaland, North Bengal, South Bengal, Pantnagar, Guntur, ICAR-IARI and BCKV-AICRP on Vegetable crops).

Agronomy: Forty days old seedlings were transplanted in the main field at a spacing of $60 \mathrm{~cm} \times 45 \mathrm{~cm}$ in randomized block design (RBD) with three replications consisting of one row of 30 plants for each entry. The crop was raised as per the recommended package of practices, uniformly applied for each plot.

Data collection: Five plants were selected randomly from each plot, tagged and observations were recorded for fifteen growth and yield related traits namely plant height $(\mathrm{cm})$, plant canopy width $(\mathrm{cm})$, number of primary branches per plant, leaf length $(\mathrm{cm})$, leaf width $(\mathrm{cm})$, days to $50 \%$ flowering, fruit length $(\mathrm{cm})$, fruit girth $(\mathrm{mm})$, fruit pedicel length $(\mathrm{cm})$, number of fruits per plant, fresh 
fruit weight $(\mathrm{g})$, dry fruit weight $(\mathrm{g})$, number of seeds per fruit, 100 seed weight $(\mathrm{mg})$ and fruit yield per plant $(\mathrm{g})$.

Statistical analysis: Average values of each parameter or characters were used for analysis. The mean values were subjected to statistical analysis (ANOVA) as suggested Panse and Sukatme (1967). Phenotypic and genotypic co-efficient of variation, heritability, and genetic advance over mean were calculated following Burton \& De-vane (1953), Weber \& Moorthy (1952) and Johnson et al., (1955).

\section{Results and Discussion}

Pooled data over three years $(2008-09,2009$ 10 and 2010-11) have been utilized to study genetic variability among the thirty seven chilli genotypes for the studied fifteen characters. The analysis of variance, presented in Table 1, clearly suggests significant differences among the genotypes for all the characters (at $\mathrm{P}=0.01$ ), indicating presence of significant genetic variability in the experimental material. This finding was in accordance with those of Khurana et al., (2003) and Varkey et al., (2005). 'Year x Genotype' interaction was significant only for two characters viz. days to $50 \%$ flowering and fruit yield per plant, indicating stable expression of most of the characters over the years.

The estimates of mean, range, genotypic coefficient of variation (GCV), phenotypic coefficient of variation (PCV), heritability $\left(\mathrm{h}^{2}\right)$ and genetic advance as percentage of mean (GA) for different characters are presented in Table 2.

Table.1 ANOVA for growth characters, yield components and yield

\begin{tabular}{|c|c|c|c|c|c|}
\hline \multirow[t]{2}{*}{ Character } & \multicolumn{5}{|c|}{ Source of Variation } \\
\hline & Rep. & Year & Genotype & $\mathbf{Y} \times \mathbf{G}$ & Error \\
\hline DF & 2 & 2 & 36 & 72 & 220 \\
\hline Plant height (cm) & 0.827 & $127.838 * *$ & $292.112 * *$ & 5.712 & 5.759 \\
\hline Plant canopy width (cm) & 4.606 & 3.634 & $249.095 * *$ & 1.904 & 2.909 \\
\hline No. of primary branches /plant & 0.478 & 0.339 & $12.497 * *$ & 0.316 & 0.352 \\
\hline Leaf length $(\mathrm{cm})$ & 0.035 & 0.172 & $15.293 * *$ & 0.055 & 0.106 \\
\hline Leaf width (cm) & 0.006 & 0.028 & $5.506 * *$ & 0.011 & 0.022 \\
\hline Days to $50 \%$ flowering & 3.360 & 6.495 & $978.284 * *$ & $5.063 * *$ & 4.927 \\
\hline Fruit length (cm) & 0.036 & 0.015 & $13.076 * *$ & 0.044 & 0.078 \\
\hline Fruit girth (mm) & 0.101 & 0.442 & $78.028 * *$ & 0.268 & 0.241 \\
\hline Fruit pedicel length $(\mathrm{cm})$ & 0.017 & 0.017 & $3.329 * *$ & 0.030 & 0.046 \\
\hline No. of fruits per plant & 2.659 & 7.073 & $641.447 * *$ & 5.653 & 9.076 \\
\hline Fresh fruit weight (g) & 0.005 & 0.009 & $2.766^{* *}$ & 0.014 & 0.016 \\
\hline Dry fruit weight (g) & 0.002 & 0.001 & $0.198 * *$ & 0.002 & 0.005 \\
\hline No. of seeds/fruit & 0.364 & $3.214 * *$ & $3187.201 * *$ & 0.526 & 0.580 \\
\hline 100 seed weight (mg) & 34.201 & 3.327 & $11195.133 * *$ & 9.460 & 21.922 \\
\hline Fruit yield per plant (g) & 7.512 & 3.681 & $12035.112 * *$ & $28.544 * *$ & 17.736 \\
\hline
\end{tabular}


Table. 2 Genetic variability parameters for different characters

\begin{tabular}{|l|c|c|c|c|c|c|}
\hline \multicolumn{1}{|c|}{ Character } & $\begin{array}{c}\text { Grand } \\
\text { Mean }\end{array}$ & Range & GCV & PCV & $\begin{array}{c}\text { Heritability } \\
\text { (h\%) }\end{array}$ & $\begin{array}{c}\text { GA as \% } \\
\text { of mean }\end{array}$ \\
\hline Plant height (cm) & 50.24 & $35.89-60.24$ & 10.17 & 11.13 & 83.49 & $\mathbf{1 9 . 1 5}$ \\
\hline Plant canopy width (cm) & 44.75 & $33.47-54.30$ & 11.48 & 11.95 & 92.32 & $\mathbf{2 2 . 7 3}$ \\
\hline $\begin{array}{l}\text { No. of primary branches } \\
\text { /plant }\end{array}$ & 6.91 & $5.24-9.67$ & 16.57 & 18.85 & 77.24 & $\mathbf{2 9 . 9 9}$ \\
\hline Leaf length (cm) & & & & & & \\
\hline Leaf width (cm) & 7.82 & $5.48-11.54$ & 16.78 & 17.29 & 94.08 & $\mathbf{3 3 . 5 2}$ \\
\hline Days to 50 \% flowering & 2.87 & $1.79-5.51$ & 27.16 & 27.68 & 96.25 & $\mathbf{5 4 . 8 8}$ \\
\hline Fruit length (cm) & 54.78 & $35.67-78.00$ & 18.88 & 19.30 & 95.66 & $\mathbf{3 8 . 0 3}$ \\
\hline Fruit girth (mm) & 7.85 & $4.38-9.77$ & 15.49 & 15.86 & 95.36 & $\mathbf{3 1 . 1 5}$ \\
\hline Fruit pedicel length (cm) & 10.44 & $5.64-17.11$ & 28.13 & 28.55 & 97.13 & $\mathbf{5 7 . 1 2}$ \\
\hline No. of fruits per plant & 3.24 & $2.56-5.88$ & 18.56 & 19.70 & 88.81 & $\mathbf{3 6 . 0 4}$ \\
\hline Fresh fruit weight (g) & 46.26 & $33.78-70.90$ & 18.04 & 19.02 & 89.96 & $\mathbf{3 5 . 2 5}$ \\
\hline Dry fruit weight (g) & 2.79 & $1.79-4.09$ & 19.77 & 20.24 & 95.35 & $\mathbf{3 9 . 7 7}$ \\
\hline No. of seeds/fruit & 0.75 & $0.50-1.07$ & 19.78 & 19.88 & 99.02 & $\mathbf{4 0 . 5 4}$ \\
\hline 100 seed weight (mg) & 66.21 & $35.76-95.99$ & 28.39 & 28.41 & 99.84 & $\mathbf{5 8 . 4 3}$ \\
\hline Fruit yield per plant (g) & 550.06 & $492.89-$ & 6.40 & 6.46 & 98.30 & $\mathbf{1 3 . 0 8}$ \\
\hline
\end{tabular}

It was clear from Table- 2 that, the character fruit yield per plant showed maximum range $(72.35-238.35)$ followed by number of seeds per fruit $(35.76$ - 95.99), days to $50 \%$ flowering $(35.67-78.00)$, number of fruits per plant $(33.78-70.90)$, plant height $(35.89$ - 60.24) and plant canopy width (33.47 54.30). The characters showing wide range of variation provide an ample scope for selecting desired types (Ukkund et al., 2007).

For most of the characters, Phenotypic Coefficient of Variation (PCV) corresponded closely to Genotypic Coefficient of Variation (GCV), which agreed well to the earlier findings of Ukkund et al., (2007). The result suggests that these traits are least affected by environment and selection for these traits on phenotypic performance would be rewarding. In few traits (number of primary branches per plant and fruit pedicel length), the estimates of PCV were greater than GCV. This indicates that the variation for these traits is not only by genotypes but also due to environment. Hence, selection based on phenotypic performance should not be recommended these traits.

Close correspondence between PCV and GCV estimates was reflected on the broad sense heritability, which were very high (more than $85 \%$ ) for all the characters except number of primary branches per plant. Burton (1952) suggested that genetic variability along with heritability should be considered for harnessing the maximum and accurate effect of selection. Johanson et al., (1955) opined that heritability in combination with genetic advance would be more reliable for predicting the effect of selection. Genetic advance is the expected genetic progress, possible through selection, over the original population.

Mean genetic advance as percent of mean was high for four traits namely fruit yield per plant (60.53), seeds per fruit (58.43), fruit girth 
(57.12) and leaf width (54.88). High value of genetic advance along with moderate GCV and high broad sense heritability was registered for these four traits. To identify the most important characters for selection, it is important to consider the values of GCV, heritability and genetic advance together. Generally high GCV coupled with high broad sense heritability and genetic advance is attributable to additive gene action (Panse, 1957), hence, early generation selection would be helpful for improving these characters. Simple selection will also be effective for the characters like dry fruit weight, fresh fruit weight, days to $50 \%$ flowering, fruit pedicel length and fruits per plant which registered moderate GCV, coupled with high heritability and moderate genetic advance.

Moderate to high heritability accompanied with low to moderately low genetic advance was recorded for plant height, plant canopy width, number of primary branches per plant, leaf length, fruit length and 100 seed weight. Low genetic advance coupled with high heritability for the trait plant height was earlier reported by Patil et al., (2008). Improvement of these characters needs selection over several successive years, preferably across locations and over different plantings, because such association of genetic parameters may be attributed to non-additive gene action (Liang and Walter, 1968) and high genotype-environment interaction, hence, simple selection will not be rewarding. Alternately, it suggests heterosis breeding for their amelioration.

\section{References}

Anonymous (2018a). Tridge: global intelligence of food \& agriculture: Chilli Pepper. https://www.tridge.com/ intelligences/other-chili-pepper/ production.
Anonymous (2018b). Horticultural Statistics at A Glance; Ministry of Agriculture \& Farmers' Welfare Department of Agriculture, Cooperation \& Farmers' Welfare, Govt. of India. Horticulture Statistics Division; pp 10-11.

Apeda (2007). http://apeda.in/agriexchange/ Market\%20Profile/one/GREEN\%20C HILLY.aspx

Burton G.W. (1952). Quantitative inheritance in grasses. Proc. $6^{\text {th }}$ Int. Grassland Cong., 1: 273-283.

Burton G.W. and De-vane E.H. (1953). Estimating heritability in tall-fescue (Festuca circundiancae) from replicated clonal material. Agron. J. 45: 478-481.

Cramer C.S. (2006). Onion trait heritability and response from selection. J. Amer. Soc. Hort. Sci., 131(5): 646-650.

Jogi, M.Y., Madalageri, M.B., Mallimar, M., Bawoor, S., Mangi, V. and Porika, H., (2017). Genetic Variability Studies in Chilli (Capsicum annuum L.) for Growth and Early Yield, Int. J. Pure App. Biosci. 5(5): 858-862.

Johanson H.W., Robinson, H.F. and Comstock, R.E. (1955. Estimates of genetic and environmental variability in Soyabean. Agron. J., 47(7): 314-315.

Khurana, D.S., Singh, P. and Hundal, J. S. (2003). Studies on genetic diversity for growth, yield and quality traits in chilli (C. annuum L.). Indian J. Hort., 60(3): 277-282.

Liang G.H.L. and Walter, T.H. (1968). Heritability estimates and gene effects for agronomic traits in grain sorghum (Sorghum vulgare). Crop Sci., 8: 7780.

Nandeshwar V.N. and Bharad S.G. (2019). Efect of planting geometry and fertigation levels on growth, yield and quality of chilli. J Krishi Vigyan, 8 (1): 63-69.

Nandi A. (1992). Genetic variability in chilli 
(Capsicum annuum L.). Indian journal of Coca Arecanut and Spices., 16 (3/4): 140-145.

Panse V. G. and Sukhatme, P. V. (1967). Statistical methods for agricultural workers, Indian Council of Agricultural Sciences, New Delhi.

Patil, S.D., Bidari, B.I., Shashidhara, G.B. and Hegde, N.K. (2008). Genetic variability in chilli (Capsicum annuиm L.) genotypes. Asian J. Hort., 3(2): 310-312.

Rajamanickam C. (2020). Assessment of Chilli (Capsicum annuum L.) hybrids for growth and yield characters. $J$ Krishi Vigyan, 8 (2): 12-15.

Ukkund K.C., Madalageri, M.B., Patil, M.P., Mulage, R. and Kotikal, Y.K. (2007). Variability studies in green chilli
(Capsicum annuum L.). Karnataka J. Agric. Sci., 20(1): 102-104.

Varkey J., Saiyed, M.P., Patel, J.S. and Patel, D.B. (2005). Genetic variability and heritability in chilli. J. Maharashtra Agric. Univ., 30(3): 346-347.

Vidyashree A.B., Allolli, T.B., Ravi, Y. and Mulge, R. (2018). Genetic Variability Studies in Byadagi Chilli (Capsicum annuum L.), Int. J. Pure App. Biosci. 6(5): 1120-1125.

Weber C. R. and Moorthy H. R. (1952). Heritable and non-heritable relationship and variability of oil content and agronomic characters in the F2 generation of soybean crosses. Agron. J., 44: 202-209.

\section{How to cite this article:}

Chandan Kumar Mondal, Pinaki Acharyya and Pranab Hazra. 2020. Studies on Genetic Variability in Chilli (Capsicum anпиит L.) in the Sundarban Region of West Bengal. Int.J.Curr.Microbiol.App.Sci. 9(12): 1938-1943. doi: https://doi.org/10.20546/ijcmas.2020.912.230 